Article

\title{
Family and Child Characteristics Associated with Foster Care Breakdown
}

\author{
Liliya A. Aslamazova ${ }^{1, *}$, Rifkat J. Muhamedrahimov ${ }^{2}$ and Elena A. Vershinina ${ }^{3}$ \\ 1 Department of Pedagogical Psychology, Adyghe State University, 208, Pervomayskaya st., \\ 385000 Maykop, Russia \\ 2 Department of Psychology, Saint-Petersburg State University, 7-9, Universitetskaya Emb., \\ 199034 St. Petersburg, Russia; rjm@list.ru \\ 3 Pavlov Institute of Physiology Russian Academy of Sciences, 6, Makarov's Emb., \\ 199034 St. Petersburg, Russia; ver_elen@mail.ru \\ * Correspondence: lilyanima@mail.ru; Tel.: +7-961-586-27-58
}

Received: 18 October 2019; Accepted: 13 December 2019; Published: 16 December 2019

\begin{abstract}
Studies examining the experience of children returned from foster care can reveal its causes and the severity of the psychological consequences, as well as the positive effect of psychological support on family functioning. Our research was aimed at the features of children and characteristics of foster families who refuse to continue parenting foster children. The study participants were comprised of families raising a foster child (Group One-182 families), and families who refused to continue parenting and returned the child (Group Two-19 families). The study was conducted using the "standardized interview for parents" and the "list of traumatic experiences of the child." The results show that the strongest contributor to foster family breakdown was the degree of the child's traumatic experience before placement (for Group One, 3.9 (1.15); Group Two, 6.1 (1.31), U = 395.0, $p<0.001$ ) and the minimal participation of the family in an intervention program (the total number of program activities the family did not participate in; for Group One, 48.5 (28.27)\%, Group Two, $95.5(2.58) \%, \mathrm{U}=67.5, p<0.001)$. Our data expand ideas about the functioning of foster families who have taken children with significant traumatic experience and indicate the need to improve the quality of psychological and social support to foster families as an important factor in preventing secondary returns.
\end{abstract}

Keywords: foster family; children; traumatic experience; intervention program; foster care breakdown

\section{Introduction}

In accordance with the National Strategy of Action for Children (1 June 2012, \# 761), there has been intensive work on the foster family system in the Russian Federation. The number of children registered in the state bank for orphan children has been reduced from 71.2 thousand in 2016, to 49.9 thousand at the beginning of 2018 [1]. According to the State report on the situation of children and families with children in the Russian Federation, at the end of 2016, 87\% of orphans had been placed in families. At the same time, there has been a growth in secondary returns: every year, about $1 \%$ of all transfers of children to a foster family are canceled (5198 children were returned in 2014; 5713 in 2015; and 5227 in 2016) [2]. Most returns occur on the initiative of the foster parents: in 2014, $4452(86 \%)$ of the children were returned; in 2015, 4952 (87\%); and in 2016, 4375 (80\%). The most common reason given by foster parents for return are: unfavorable appearance; impaired development and behavior of the foster child (29\% returns); multiple health problems (18\%); poor heredity $(10 \%)$; serious conflicts in the family connected with the reception of the child (10\%); uncertainty about their own competence as a substitute parent (6\%); and the negative impact of the foster child on biological children $(5 \%)[3,4]$. 
Studies on the effect of the permanence of foster placement on the well-being of foster children attests to the importance of stable placement for the child's ability to form a healthy secure relationship with a caring adult [5-7]. Such a relationship has a long-term effect on the subsequent development and functioning of the child, including his/her ability to cope with stress, learn, and build relationships with other adults [8,9]. It has been shown that children who have experienced a break-up with a foster family experience deep stress, a sense of loss and non-belonging, and a fear of forming new relationships $[10,11]$.

An analysis of the reasons for foster families' refusal to continue identified both legal reasons (imperfection of legislation, lack of responsibility for refusing to bring up) [12], and reasons related to the peculiarities of the foster children (appearance, development, behavior, health, lack of social welfare skills, age-related difficulties) [13], or the substitute parents (low level of readiness to receive a child; inadequate motivation, especially financially oriented; mismatch of expectations and reality; disappointment, rejection of the child; confusion, emotional exhaustion, etc.) $[12,13]$. Studies revealed the severity of the psychological consequences of returns for foster children and substitute parents $[13,14]$, and the positive effect of psychological support on the functioning of the substitute family [15-17]. At the same time, there is a lack of information on what conditions are conducive to stable and high-quality living conditions for foster children in Russian families, on the effectiveness of child and family support programs, and on the factors associated with foster care breakdown. The purpose of the current study was to explore the features of children and characteristics of substitute families in connection with the foster care breakdown experience.

\section{Materials and Methods}

\subsection{Participants}

This paper presents the results of a study of 201 foster families supervised by the Republic of Adygheya's (Russian Federation) foster families' assistance center. This group included families who continued to raise a foster child (Group One) and those who dropped out and returned the child (Group Two). In accordance with the legislation of the Russian Federation, before accepting the child into the family, all prospective parents take an 80.5 academic hour mandatory training program. The training program includes topics on legal and social aspects of fostering, medical care for children, child development, as well as the development and behavior of children with institutional experience. After completion of the program, parents are registered with the guardianship authority, the governmental placing agency that controls the foster family care system. All families receive professional support and intervention by the same foster families' assistance center. No contacts of foster children with birth families were observed. The key characteristics of the foster families and the children are presented in Table 1.

Table 1. The number of research participants $(\mathrm{N})$, including in Group One $\left(\mathrm{n}_{1}, \%\right)$ and Group Two $\left(\mathrm{n}_{2}\right.$, $\%)$, according to their characteristics, and results of intergroup comparison $\left(x^{2}, p\right)$.

\begin{tabular}{|c|c|c|c|c|c|c|}
\hline \multirow{2}{*}{ Sample Characteristics } & \multirow{2}{*}{$\mathbf{N}$} & \multicolumn{2}{|c|}{ Group 1} & \multicolumn{2}{|c|}{ Group 2} & \multirow{2}{*}{$x^{2}$} \\
\hline & & $\mathbf{n}_{1}$ & $(\%)$ & $\mathbf{n}_{2}$ & $(\%)$ & \\
\hline \multicolumn{7}{|c|}{ Foster Families } \\
\hline Total & 201 & 182 & 90.5 & 19 & 9.5 & 0.75 \\
\hline couples' families & 163 & 149 & 81.9 & 14 & 73.7 & \\
\hline single-parent families & 38 & 33 & 18.1 & 5 & 26.3 & \\
\hline $\begin{array}{l}\text { Financial situation (per family } \\
\text { member per month) }\end{array}$ & & & & & & $15.59 * * *$ \\
\hline high (over 550 dollars) & 12 & 11 & 6 & 1 & 5.3 & \\
\hline average (150-450 dollars) & 157 & 148 & 81.3 & 9 & 47.4 & \\
\hline low (less than 150 dollars) & 32 & 23 & 12.6 & 9 & 47.4 & \\
\hline
\end{tabular}


Table 1. Cont.

\begin{tabular}{|c|c|c|c|c|c|c|}
\hline \multirow{2}{*}{ Sample Characteristics } & \multirow{2}{*}{$\mathbf{N}$} & \multicolumn{2}{|c|}{ Group 1} & \multicolumn{2}{|c|}{ Group 2} & \multirow{2}{*}{$x^{2}$} \\
\hline & & $\mathrm{n}_{1}$ & $(\%)$ & $\mathrm{n}_{2}$ & $(\%)$ & \\
\hline \multicolumn{7}{|c|}{ Foster Families } \\
\hline Place of living & & & & & & $2.28^{+}$ \\
\hline city & 36 & 35 & 19.2 & 1 & 5.3 & \\
\hline countryside & 165 & 147 & 80.8 & 18 & 94.7 & \\
\hline $\begin{array}{l}\text { Degree of participation in } \\
\text { intervention program }\end{array}$ & & & & & & $41.04^{* * *}$ \\
\hline 1-minimum & 68 & 49 & 26.9 & 19 & 100 & \\
\hline 2 -average & 63 & 63 & 34.6 & 0 & 0 & \\
\hline 3-maximum & 70 & 70 & 38.5 & 0 & 0 & \\
\hline Foster mother education & 199 & 180 & 90.5 & 19 & 9.5 & 2.16 \\
\hline university & 61 & 57 & 31.7 & 4 & 21.1 & \\
\hline incomplete university & 5 & 5 & 2.8 & 0 & 0 & \\
\hline college & 87 & 76 & 42.2 & 11 & 57.9 & \\
\hline school & 46 & 42 & 23.3 & 4 & 21.1 & \\
\hline Foster father education & 165 & 151 & 91.5 & 14 & 8.5 & 1.12 \\
\hline university & 30 & 26 & 17.2 & 4 & 28.6 & \\
\hline college & 110 & 102 & 67.5 & 8 & 57.1 & \\
\hline school & 25 & 23 & 15.2 & 2 & 14.3 & \\
\hline Foster mother employment & 199 & 180 & 90.5 & 19 & 9.5 & 1.38 \\
\hline works & 115 & 106 & 58.9 & 9 & 47.4 & \\
\hline does not work & 70 & 61 & 33.9 & 9 & 47.4 & \\
\hline retired & 14 & 13 & 7.2 & 1 & 5.3 & \\
\hline Foster father employment & 165 & 151 & 91.5 & 14 & 8.5 & 0.99 \\
\hline works & 155 & 141 & 93.4 & 14 & 100 & \\
\hline does not work & 2 & 2 & 1.3 & 0 & 0 & \\
\hline retired & 8 & 8 & 5.3 & 0 & 0 & \\
\hline \multicolumn{7}{|c|}{ Foster Children } \\
\hline Gender & & & & & & 0.05 \\
\hline Boys & 100 & 91 & 50 & 9 & 47.4 & \\
\hline Girls & 101 & 91 & 50 & 10 & 52.6 & \\
\hline Developmental status & & & & & & 1.14 \\
\hline typical & 108 & 100 & 54.9 & 8 & 42.1 & \\
\hline with disability & 93 & 82 & 45.1 & 11 & 57.9 & \\
\hline Separate room for child & & & & & & 0.15 \\
\hline yes & 27 & 25 & 13.7 & 2 & 10.5 & \\
\hline no & 174 & 157 & 86.3 & 17 & 89.5 & \\
\hline Number of traumatic situations & & & & & & $84.67^{* * *}$ \\
\hline $1-4$ & 138 & 136 & 74.7 & 2 & 10.5 & \\
\hline $5-8$ & 63 & 46 & 25.3 & 17 & 89.5 & \\
\hline
\end{tabular}

The age of children (M [SD]) in Group One was 6.9 years (3.18) (range: 0.71-14.98); in Group Two, it was 9.3 years (2.99) (2.82-14.01). The age of admission of children to the institution was, correspondingly, 3.3 (2.36) (0.01-13.2) and 4.5 (1.85) (0.3-8.1); the length of stay in an institution was 3.6 (2.24) (0.01-11.0) and 4.8 (2.29) (1.1-11.4). The study was done two to four weeks after the child was admitted to the foster care family. The information on the foster care breakdown was obtained later based on the families' assessment. 
The data presented in our study were collected within routine regular work of the Center for Foster Families and were analyzed in order to understand the results of the professional activities provided in the Center. The work of the Center, including assessment of children and parents, is regimented by the Regulation on the Center for Foster Families. According to the Regulation, all foster parents signed a written form of the contract, which regulates services provided by the Center. All parents also sign the informed consent form, including consent for assessments of the foster child and family members (according to the Russian Federation Federal Law ("On Personal Data", No. 152, 2006).

Ethics approval and participation consent: All procedures were carried out within the framework of support of foster families by the Center for Psychological, Medical, and Social Assistance (Maykop, Republic of Adygheya) in accordance with the legislation of the Russian Federation.

Availability of Data and Materials: The datasets used and analyzed during the current study are available from the corresponding author on reasonable request.

\subsection{Research Tools}

The 54 items of the "standardized interview for parents" [18] were used to examine the foster families' socio-demographic characteristics, including the family's place of residence and the availability of a separate room for the child. The "list of traumatic experiences of the child" [18], which consists of 20 events (for example, mother/father's death, mother/father's alcoholism, etc.), was applied to study what traumatic experience may have occurred in the child's life before he/she was accepted into a foster family. The foster parents were interviewed about these traumatic events two to four weeks after the child was taken into the family.

\subsection{Statistical Analysis}

The frequency of occurrence of the foster families' and children's characteristics (in percent) between two groups were compared using the Chi-Square $\left(x^{2}\right)$ test. To compare the mean values of characteristics, the Mann-Whitney U test was used. The correlations between the characteristics were calculated using Spearman's rank correlation coefficient. Binary logistic regression was employed to identify the family and child characteristics causing the foster care breakdown. All analyses were conducted using SPSS Inc. software.

\section{Results}

Groups One and Two differed in the distribution of four of the characteristics presented in Table 1:

1. The financial situation of the substitute family (refusal is more frequent in families with a lower financial position; $\left.x^{2}(2, \mathrm{~N}=201)=15.59, p<0.001\right)$;

2. The number of traumatic situations suffered by the foster child (family breakdown is manifested in a larger number of them; $\left.x^{2}(7, N=201)=84.67, p<0.001\right)$;

3. The degree of family participation in the intervention program (the minimum degree in $26.9 \%$ of families in Group One and 100\% participation in Group Two; $\left.x^{2}(2, \mathrm{~N}=201)=41.04, p<0.001\right)$; and

4. As a trend, the foster family's location (more often when living in the countryside; $\left.\mathrm{x}^{2}(1, \mathrm{~N}=201)=2.28, p<0.10\right)($ see Table 1$)$.

There were no differences between the frequencies of distribution between the two groups $(p>0.10)$ for the other indicators listed in Table 1.

The age of the children in Group Two was higher than in Group One: (6.9 (3.18) vs. 9.3 (2.99); $\mathrm{U}=957.0, p<0.001)$. The children in Group Two had a higher age of admission to the institution (3.3 (2.36) and 4.5 (1.85); $\mathrm{U}=1072.0, p=0.006)$, as well as a longer period of institutionalization (3.6 (2.24) and 4.8 (2.29); $\mathrm{U}=1126.0, p=0.012$ ). Due to the high correlation between the age of children at the time of study and (1) the age of their admission to the institution (in Group One, $\mathrm{r}=0.74, p<0.001$, in Group Two, $\mathrm{r}=0.537, p=0.018$ ), (2) the length of institutionalization (respectively, $\mathrm{r}=0.659, p<0.001$ and 
$r=0.734, p<0.001$ ), and (3) the age of admission to a foster family (for both groups $r=1.00, p<0.001$ ), the age of children was subjected to further analysis.

At the next stage, binary logistic regression was employed, with the foster care breakdown experience as the dependent variable and the following characteristics as independent variables: family's financial situation (groups of families with medium and high financial status were combined due to the relatively low occurrence of high income in both groups); place of residence; degree of participation in the intervention program (a percentage of the total number of program activities the family did not participate in; for Group One, 48.5 (28.27)\%, Group Two, $95.5(2.58) \%$, U = 67.5, $p<0.001$ ); the number of traumatic situations the child experienced (Group One, 3.9 (1.15); Group Two, 6.1 (1.31), $\mathrm{U}=395.0, p<0.001)$; and the child's age.

The analysis was completed after two steps of logistic regression, showing a $96.5 \%$ correct classification with the identification of the determinant family and the child's characteristics of the foster care breakdown (see Table 2). After the first step, the probability of a greater number of traumatic situations in children from Group Two was 4.1 times higher than from Group One; $\beta=1.41$, SE $=0.27$, $p<0.001)$. After the second step, the probability of a greater number of traumatic situations in children from Group Two was 2.73 times higher than from Group One; $\beta=1.0 ; \mathrm{SE}=0.37 ; p=0.007$ ), and the probability of a greater percentage of non-participation in program activities for families from Group Two was 1.78 times higher than from Group One; $\beta=0.59 ; \mathrm{SE}=0.19 ; p=0.002$ ).

Table 2. The results of binary logistic regression ( $\beta$, SE, OR with $95 \%$ confidence limits, $p)$.

\begin{tabular}{|c|c|c|c|}
\hline Characteristics & B & SE & OR (95\% CI) \\
\hline $\begin{array}{c}\text { Step } 1 \\
\text { Number of traumatic situations } \\
\text { Constant }\end{array}$ & $\begin{array}{c}1.41^{* * *} \\
-9.21\end{array}$ & $\begin{array}{l}0.27 \\
1.53\end{array}$ & $4.10(2.40-7.0)$ \\
\hline $\begin{array}{c}\text { Step } 2 \\
\text { Number of traumatic situations } \\
\text { Number of non-participation in the intervention program } \\
\text { Constant }\end{array}$ & $\begin{array}{l}1.0^{* *} \\
0.59^{* *} \\
-60.16\end{array}$ & $\begin{array}{c}0.37 \\
0.19 \\
18.08\end{array}$ & $\begin{array}{l}2.73(1.31-5.68) \\
1.78(1.24-2.61)\end{array}$ \\
\hline
\end{tabular}

\section{Discussion}

The present study deals with the impact of the foster families' and children's characteristics on the continuation or rejection of foster care. The results show that the most significant contributors to foster care breakdown are the number of traumatic situations the child experienced before admission to a foster family and the minimal family participation in an intervention program.

Highlighting the foster child's traumatic experience as a significant contributor to the failure of the foster care placement supports previous studies about the vulnerability of children who are in foster care [15] because they are victims of abuse and neglect [19]. These children experience more somatic disorders, emotional, behavioral, and educational difficulties [19], which significantly complicate their relationships with foster parents [17], complicate family integration [18], and increase the likelihood of failure [20]. Negative experience is a factor that provokes adaptive difficulties and behavioral disorders [21], which eventually become reasons for the foster parents' reluctance to continue hosting the child [22,23].

Our results also indicate that families who returned their foster children rarely attended intervention program activities. Their inefficiency in caring for foster children is reflected in their passivity about participating in the support program [18]. Thus, the program team was limited in its ability to detect problems [24] and to include them in foster care breakdown prevention programs.

The first step of analysis showed that the refusal to continue as foster parents occurs more often in families with lower financial status, as well as those in rural areas. On the one hand, these data 
confirm previous findings that a foster family's material well-being is a factor of its viability [25] and are consistent with data showing high levels of returns of foster children from rural families [26]. On the other hand, these data were not confirmed by the results of the logistic regression, which may indicate their contribution to the child's upbringing continuation indirectly through the indicators identified by the regression analysis. Since foster care is associated with high financial expenses, low material wealth is a risk factor and in combination with other factors, can lead to the family abandoning the child. According to the literature, returns of children from rural families may also be associated with the distance of families' residences from the support services, which would make participation in support activities more difficult $[18,27]$. However, the rural foster families in our study lived within 1 to $1.5 \mathrm{~h}$ of the center, which is relatively comparable to the access time for urban families. The proximity of the studied families to the foster families' assistance center reduces the degree of isolation of rural families and the lack of community-based stimulus for them and decreases the possibly of the breakdowns. The results of the binary logistic regression reveal that the place of foster family residence is not a significant contributor to foster care breakdown.

Our study shows that the age of children rejected by foster families was higher than the age of children who were accepted, and correlates with both the age of the child's admission to an orphanage and the duration of stay in that institution, as well as the age of admission to foster families. The literature identifies the older age of the child at the time of placement as an absolute risk factor for failure [24,28-31]. At the same time, the results also indicate an indirect influence of the age factor on the family's decision to refuse to continue the child's upbringing. The number of traumatic situations the child experienced may be higher in foster children of older age. The adaptation process in foster families might be improved if prospective parents were selected and matched to children based on their skill set and preferences, including a preference for children of a specific age. Unfortunately, the newly created foster family system in the Russian Federation does not provide this type of matching.

A child's gender, and whether he or she had typical development or disabilities, did not appear as a significant indicator of the success of placement. Although the insignificance of the gender factor is consistent with the results of other studies [26], the insignificance of the second indicator, on the one hand, contradicts the literature, showing that health-related developmental disorders are a risk factor for raising and keeping a child in a family, and create a high need of the family for early intervention [16]; on the other hand, they are consistent with the general results in this area [24]. The ambiguity could be caused by differences in the features of health and development of the foster children studied by different authors, as well as by concomitant factors, such as when the health problems are accompanied by emotional and behavioral problems [28].

Finally, our results show that indicators such as family size, availability of a separate room for a foster child, and the educational level and employment of the foster parents are not significant determinants of the success or failure of foster placement. This is consistent with other studies on family composition's effect on the success of foster care [32], as well as those on the relationship between the education of the parents and the probability of the child being returned [28].

Our results on the contribution of family characteristics to keeping the foster child in the family emphasize the need for the organizations responsible for the training and support of foster families to take them into account. We need organizational and legal frameworks for the comprehensive involvement of existing and new foster families in intervention programs, and new forms of support, including for families living in remote and rural areas. Training for foster parents should include not only information on the psychological trauma of orphans and children left without parental care but should also teach them how to deal with a traumatized child and establish the importance of participating in a professional support program. Moreover, the staff of the foster families' assistance center should be trained to help children and their new parents cope with the children's traumatic experiences, including a history of neglect and violence in the biological family and social and emotional deprivation in institutions. The newly created system should include a requirement that prospective foster parents be selected based on the children's needs. 
The limitations of this study include the fact that its results cannot be directly applied to foster children who have experienced a secondary return. Information about the children's traumatic experiences before their admission to the family was obtained from the statements of the foster parents and may differ from expert evaluations (support staff).

\section{Conclusions}

Raising a foster child is a complex and painstaking process, an important component of which is creating high-quality stable family conditions for the child. Our results show that among the characteristics of both the children and foster families, the strongest contributors to foster care failure were the child's traumatic experiences before foster care and the foster family's minimum degree of participation in programs of psychological support. It seems promising to continue studying factors that increase the chances of foster care success, including foster family dynamics and the children's attachment to their foster parents. The results can expand our scientific understanding of the functioning of foster families and provide guidance in improving the current foster care system in the Russian Federation.

Author Contributions: Conceptualization, L.A.A. and R.J.M.; Methodology, L.A.A. and R.J.M.; Software, E.A.V.; Validation, L.A.A., R.J.M. and E.A.V.; Formal Analysis, E.A.V.; Investigation, L.A.A.; Resources, L.A.A.; Data Curation, L.A.A.; Writing-Original Draft Preparation, L.A.A.; Writing-Review Editing, L.A.A. and R.J.M.; Visualization, L.A.A., R.J.M. and E.A.V.; Supervision, R.J.M.; Project Administration, R.J.M.; Funding Acquisition, L.A.A.

Funding: This research received no external funding.

Acknowledgments: The authors would like to express their gratitude to all those who helped conduct this research, especially Antonina Safonova, and all of the families involved in the study.

Conflicts of Interest: The authors declare no conflict of interest.

\section{References}

1. The number of children registered in the state data bank on children left without parental care at the beginning of the year. Adoption in Russia: Internet project of the Ministry of Education and Science of the Russian Federation. Available online: http://www.usynovite.ru/statistics/2015/2/ (accessed on 3 June 2019).

2. State Report on the Situation of Children and Families with Children in the Russian Federation (in 2016). Ministry of Labor and Social Protection of the Russian Federation, 2016. Available online: https://rosmintrud. ru/docs/mintrud/protection/474 (accessed on 11 December 2019).

3. Semiya, G.V.; Zaitsev, G.O.; Zaitseva, N.G. Monitoring the Situation of Orphans and Children Left without Parental Care, and the Development of Family Forms of Their Device in the Central Federal District in 2008 (third annual report); Variant: Moscow, Russia, 2009; 180p.

4. Report of the Commissioner for the Rights of the Child in the Novosibirsk region. Special report on the problems of substitute families in the Novosibirsk region (in 2017). Novosibirsk. 2017. Available online: https://nskdeti.nso.ru/page/18 (accessed on 11 December 2019).

5. Harden, B.J. Safety and stability for foster children: A developmental perspective. Child. Fam. Foster Care 2004, 14, 30-47. Available online: https://www.ncbi.nlm.nih.gov/pubmed/15072017 (accessed on 15 March 2019). [CrossRef]

6. Leathers, S.J. Foster children's behavioral disturbance and detachment from caregivers and community institutions. Child. Youth Serv. Rev. 2002, 24, 239-268. [CrossRef]

7. Williams-Mbengue, N. Permanency: A Key Concept for Children in Foster Care. Available online: http://www.ncsl.org/documents/cyf/movingchildrenoutofcare.pdf (accessed on 15 March 2019).

8. Gauthier, Y.; Fortin, G.; Jeliu, G. Clinical application of attachment theory in permanency planning for children in foster care: The importance of continuity of care. Infant Ment. Health J. 2004, 25, 379-396. [CrossRef]

9. Rubin, D.M.; Alessandrini, E.A.; Feudtner, C.; Mandel, D.S.; Localio, A.R.; Hadley, T. Placement stability and mental health costs for children in foster care. Pediatrics 2004, 113, 1336-1341. [CrossRef] 
10. Committee on Early Childhood, Adoption and Dependent Care. Developmental Issues for Young Children in Foster Care. Pediatrics 2000, 106, 1145-1150. Available online: https://pediatrics.aappublications.org/ content/106/5/1145 (accessed on 15 March 2019). [CrossRef]

11. The Center for Human Services. A Literature Review of Placement Stability in Child Welfare Service: Issues, Concerns, Outcomes and Future Directions; The University of California: Davis, CA, USA, 2008; pp. 4-14. Available online: http://www.childsworld.ca.gov/res/pdf/PlacementStability.pdf (accessed on 15 March 2019).

12. Lyovushkin, A.N.; Danilova, I.S. "Secondary orphanhood" and the response of public authorities to the refusal of substitute parents of a child. Authority 2014, 8, 159-163.

13. Osipova, I.I. The phenomenon of secondary orphanhood in modern Russia. Bull. Vyatkiyi State Univ. 2008, 4, $138-143$.

14. Kuftyak, E.V. Protective behavior of returned orphans. Bull. Kostroma State Univ. 2012, 18, $209-212$.

15. Allen, J.; Vostanis, P. The impact of abuse and trauma on the developing child: An evaluation of a training programme for foster carers and supervising social workers. Adopt. Foster. 2005, 29, 68-81. [CrossRef]

16. Leslie, L.; Gordon, J.; Meneken, L.; Premji, K.; Michelmore, K.; Ganger, W. The physical, developmental, and mental health needs of young children in child welfare by initial placement type. J. Dev. Behav. Pediatr. 2005, 26, 177-185. [CrossRef]

17. Dozier, M. Challenges of foster care. Attach. Hum. Dev. 2005, 7, 27-30. [CrossRef] [PubMed]

18. Oslon, V.N. The Living Arrangement of Orphans: Professional Substitute Family; Genesis: Moscow, Russia, 2006; 368p, ISBN 5-98563-055-2.

19. Forkey, H.; Garner, A.; Nalven, L.; Schilling, S.; Stirling, J. Helping Foster and Adoptive Families Cope with Trauma; American Academy of Pediatrics and Dave Thomas Foundation for Adoption. 2015. Available online: https://www.aap.org/en-us/advocacy-and-policy/aap-health-initiatives/healthy-foster-care-america/ Documents/Guide.pdf (accessed on 15 March 2019).

20. Harkin, C.; Houston, S. Reviewing the Literature on the Breakdown of Foster Care Placements for Young People: Complexity and the Social Work Task. Child Care Pr. 2016, 22, 98-112. [CrossRef]

21. Felitti, V.; Anda, R.F.; Nordenberg, D.; Williamson, D.F.; Spitz, A.M.; Edwards, V.; Koss, M.P.; Marks, J.S. Relationship of childhood abuse and household dysfunction to many of the leading causes of death in adults: The Adverse Childhood Experiences (ACE) Study. Am. J. Prev. Med. 1998, 14, 245-258. [CrossRef]

22. Brown, J.D.; Bednar, L.M. Foster parent perceptions of placement breakdown. Child. Youth Serv. Rev. 2006, 28, 1497-1511. [CrossRef]

23. Mnisi, R.; Botha, P. Factors contributing to the breakdown of foster care placements: the perspectives of foster parents and adolescents. Soc. Work Maatskaplike Werk. 2016, 52, 227-244. [CrossRef]

24. Palacios, J.; Rolock, N.; Selwyn, J.; Barbosa-Ducharne, M.A. Adoption Breakdown: Concept, Research and Implications. Res. Soc. Work Pract. 2018, 29, 130-142. [CrossRef]

25. Krasnova, V.G.; Palkina, T.S. Material well-being of a substitute family as one of the indicators of its viability. Bull. Volsu 2012, 3, 221-226.

26. Leonova, E.E. Socio-pedagogical problems of the return of children from substitute families. News Sarat. Univ. 2017, 3, 283-286.

27. Zakharova, K.V.; Vasilyeva, M.I. The experience of raising children in substitute families in the village. Personal. Family. Soc. Quest. Pedagog. Psychol. 2013, 35, 123-129.

28. Makhnach, A.V.; Prikhozhan, A.M.; Tolstykh, N.N. Psychological Diagnosis of Candidates for Substitute Parents: A Practical Guide; Publishing House "Institute of Psychology of the Russian Academy of Sciences": Moscow, Russia, 2013; 219p.

29. Adamson, A. Fostering adolescents. Child Care Pract. 2005, 11, 91-96.

30. López, M.; Del Valle, J.; Montserrat, C.; Bravo, A. Factors Affecting Foster Care Breakdown in Spain. Span. J. Psychol. 2011, 14, 111-122. [CrossRef] [PubMed]

31. Santen, E. Factors associated with placement breakdown initiated by foster parents-empirical findings from Germany. Child Fam. Soc. Work. 2015, 20, 191-201. [CrossRef]

32. Sviridov, A.N. Socio-pedagogical factors of successful substitute parenting. Bull. Altai State Pedagog. Univ. 2012, 11, 32-37.

(C) 2019 by the authors. Licensee MDPI, Basel, Switzerland. This article is an open access article distributed under the terms and conditions of the Creative Commons Attribution (CC BY) license (http://creativecommons.org/licenses/by/4.0/). 